NIHON REOROJĪ GAKKAISHI Vol. 24, No. 2, 87 91 (1996)

(C1996 The Society of Rheology, Japan

\title{
論文
}

Nonlinear Behaviors of Poly (methyl methacrylate) Subjected to High Strain

Rate Stretching and Stress Relaxation in the Rubbery Temperature Range.

Shin'ya Yoshioka, Tomomi Sakamoto, Yukuo NanzaI

Faculty of Engineering, Osaka City University,

Sumiyoshi-ku, Osaka 558, Japan

The concept of shear-induced structural change, which has been quite successful in interpreting nonlinear viscoelasticity of amorphous polymers in the glassy region, was extendedly examined for nonlinearlity in large deformation behaviors of polymethyl methacrylate (PMMA) in the rubbery temperature range. At temperatures above the glass transition temperature, $T_{\mathrm{g}}$, the PMMA specimens were stretched at high strain rates to various large strains and then subjected to stress relaxation. Even at temperatures much higher than $T_{\mathrm{g}}$, a well-defined yield point was observed at a strain of around 0.1 at relatively higher strain rates. The appearance of the yield point was always accompanied by a substantial reduction of the relaxation modulus at short times in the glass-to-rubber transition range. This reduction gives evidence of facilitated rearrangement of chain segments probably due to the shear-induced structural change independently of chain disentanglements. Hence, it is concluded that the shear-induced structural change is likely to occur also in the rubbery liquid state of the polymer system, and the mechanism of the yield observed in the rubbery range can essentially be identified with that of the yield in the glassy range.

Key Words: Nonlinear viscoelasticity/Shear-induced structural change/Yielding/Amorphous polymer/Rubbery temperature range

\section{ゴム状温度領域におけるポリメタクリル酸メチルの伸長大変形 および緩和の非線形挙動}

\author{
吉岡 真弥*, 阪本 知己*, 南齋 征夫*
}

（原稿受理:1995年8月8日）

\section{1. 緒言}

無定形高分子は大変形に対して一般に非線形な粘弾性応答を示 す. ガラス転移温度 $T_{\mathrm{g}}$ 以上のメルト状態では, ひずみ速度の増 大ととあに粘度が低下するシィアシンニング1)あるいは大変形応 力緩和応答の線形応答からの逸脱 ${ }^{2}+$ などがこの非線形の例として よく知られている.これらは主に骨格鎖の絡み合い構造の変化に より説明されてきている ${ }^{1), 2)}$. 一方, $T_{\mathrm{g}}$ 以下のガラス状態では, 等速変形時の降伏に代表される非線形応答が観察される．この非，

*大阪市立大学工学部 $\quad$ T558 大阪市住吉区杉本 3 丁目 3-138
線形応答については，一部に異なった議論はあるあのの ${ }^{3)}$, 変形 に伴うガラスの構造変化がその起源と考えられるようになってき ている ${ }^{4) ~ 8)}$. 筆者らは高分子ガラスの大変形機構に関するこれま での一連の研究により, 大変形によって未変形時の準平衡ガラス 構造が変形条件(温度, ひずみ速度など)によって定まる非平衡ガ ラス構造(メルト構造あるいは液状構造とも呼んでいる) へと等温 構造転移することを実験的に明らかにし(9) 14), この構造転移が 変形の増大とともに連続的に進行すると考えられること，ならび に，この連続的な構造変化の過渡応答として降伏が発現すると考 えられることを単純な非線形の力学模型を用いた考察などにより 示してきている99,12),15),16). このように，無定形高分子がメルト 
およびガラス状態において示す大変形時の非線形粘弾性挙動は, それぞれ異なったメカニズムによって発現するすのとして議論さ れてきている.

さて, 線形粘弾性の議論においてよく知られているように, $T_{\mathrm{g}}$ 以上の温度領域においても高分子材料がきわめて短時間側で示す 緩和挙動はガラス的である.つまり，メルト状態において十分な 熱エネルギを有していても，分子鎖はきわめて短時間側では局所 的にしか緩和できない，このようなタイムスケールで高分子メル 卜に有限変形を加えた場合, ガラス状態と同様の非線形が現れる かどうかを調べることは無定形高分子の変形機構に関する一般的 な理解を深める上で重要と考えられる．しかしながらこのような 観点に立った検討はほとんどなされていない，そこで本研究で は, $T_{\mathrm{g}}+8^{\circ} \mathrm{C}$ から $T_{\mathrm{g}}+40^{\circ} \mathrm{C}$ のわゆるゴム状温度領域において線 状無定形ポリメタクリル酸メチル(PMMA)を高速で伸長大変形 させた際の応力ーひずみ関係, および, 大変形後の応力緩和挙動を 測定し, 転移およびゴム領域における無定形高分子の変形挙動と ガラス領域における降伏，すなわち，ガラスの等温構造変化に基 づく非線形挙動との関係について考察した.

\section{2. 実験方法}

試料には市販の厚さ $0.8 \mathrm{~mm}$ の PMMA 注型シート(三菱レーヨ ン製アクリライト L)を用いた。 GPC 測定より求めたこの試料の 数平均分子量 $M_{\mathrm{n}}$ および重量平均分子量 $M_{\mathrm{w}}$ は, それぞれ, 132,000 および 398,000 であり, 線形緩和弾性率の温度依存性か ら, 粘弾性緩和の見かけの活性化エネルギーがピークを示す温度 として求めたガラス転移温度 $T_{\mathrm{g}}$ は $116^{\circ} \mathrm{C}$ であった。このシート から $50 \mathrm{~mm} \times 4 \mathrm{~mm} \times 0.8 \mathrm{~mm}$ の平行試験部を有する試験片を機械 加工により切り出し, $T_{\mathrm{g}}$ よりあ十分に高温の $130^{\circ} \mathrm{C}$ において 2 時 間保持した後 1 時間に $3^{\circ} \mathrm{C}$ の冷却速度で室温まで徐冷する熱処理 の後実験に供した.

試験片の延伸は, ゲージ長 $50 \mathrm{~mm}$ の試験片に $150 \mathrm{~mm}$ までの変 位(公称ひずみで表現すれば $300 \%$ )を最高 $20 \mathrm{~s}^{-1}$ の等真ひずみ速 度で加えることのできる自作試験機により行った。この試験機は
時間に対して指数関数的に増加する変位を等速回転するカムによ り作り出してアクチュエータを動作させる機構を有する．力ムの 精度に依存する真ひずみ速度の設定速度からのズレは 0 - $5 \%$ の範囲にあった。

等真ひずみ速度延伸試験は供試材の $T_{\mathrm{g}}$ より屯高温の 124,139

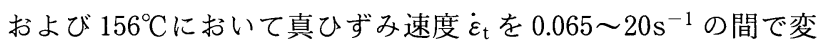
化させて行った. 応力緩和の測定は, 温度 124,139 および $156^{\circ} \mathrm{C}$ のもとで, $\dot{\varepsilon}_{\mathrm{t}}=0.20$ および $2.0 \mathrm{~s}^{-1}$ の等真ひずみ速度で延伸を加 え, 真ひずみ $\varepsilon_{\mathrm{t}}$ が所定の值に達した時点で延伸を停止して行っ た. 真ひずみ $\varepsilon_{\mathrm{t}}=0.077$ (公称ひずみで 0.080 )を任意に選んだ単位 ひずみ量として，その $1.0,2.0,4.0,8.0$ および 16 倍の 5 段階 $\left(\varepsilon_{\mathrm{t}}\right.$ $=0.077 \sim 1.23)$ の值を緩和開始時のひずみ量とした. 以下では簡 単のため, たとえば単位ひずみ量の 2 倍のひずみを $\times 2$ などと略 記することにする．緩和応力は延伸停止の約 $10^{-2} \mathrm{~s}$ 後から約 $10^{4} \mathrm{~s}$ の間測定した.

\section{3. 実験結果}

\section{$3 \cdot 1$ 等真ひずみ速度延伸}

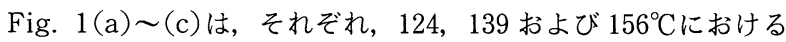
等真ひずみ速度延伸により得られた試験片の真応力 $\sigma_{\mathrm{t}}$-真ひずみ $\varepsilon_{\mathrm{t}}$ 関係を真ひずみ速度 $\varepsilon_{\mathrm{t}}$ をパラメ夕として示したあのである. 縦 軸の $\sigma_{\mathrm{t}}$ は試験部が体積变化なく, かつ, 均一に变形したものとし て算出した，図にみられるように， $\sigma_{\mathrm{t}}-\varepsilon_{\mathrm{t}}$ 曲線は温度およびひず み速度に依存して 3 つのパターンの形状で現れた。 それらは, 形 状の単純な順にそれぞれ，(1)たとえば $156^{\circ} \mathrm{C}, \dot{\varepsilon}_{\mathrm{t}}=0.065 \mathrm{~s}^{-1}$ の曲線 のように, 延伸開始から $\varepsilon_{\mathrm{t}}=0.5$ 程度まで $\sigma_{\mathrm{t}}$ が $2 \sim 3 \mathrm{MPa}$ の傾き で直線的に増加した後, その傾きを増しながら $\sigma_{\mathrm{t}}$ が増加を続け たもの，(2)たとえば $139^{\circ} \mathrm{C} ， \dot{\varepsilon}_{\mathrm{t}}=2.0 \mathrm{~s}^{-1}$ の場合のように， $\sigma_{\mathrm{t}}$ が 10 $\mathrm{MPa}$ を超える初期弾性率で立ち上がった後 $\varepsilon_{\mathrm{t}}=0.1$ 付近までに傾 きが連続的に低下し, それ以降は(1)の曲線を比例的に高応力側へ シフトしたような増加挙動を示したもの, および, (3)たとえば $124^{\circ} \mathrm{C}, \dot{\varepsilon}_{\mathrm{t}}=20 \mathrm{~s}^{-1}$ の曲線のように， $\sigma_{\mathrm{t}}$ がまず $100 \mathrm{MPa}$ オーダーの 初期弾性率で直線的に立ち上がった後徐々に傾きが減少して $\varepsilon_{\mathrm{t}}=$
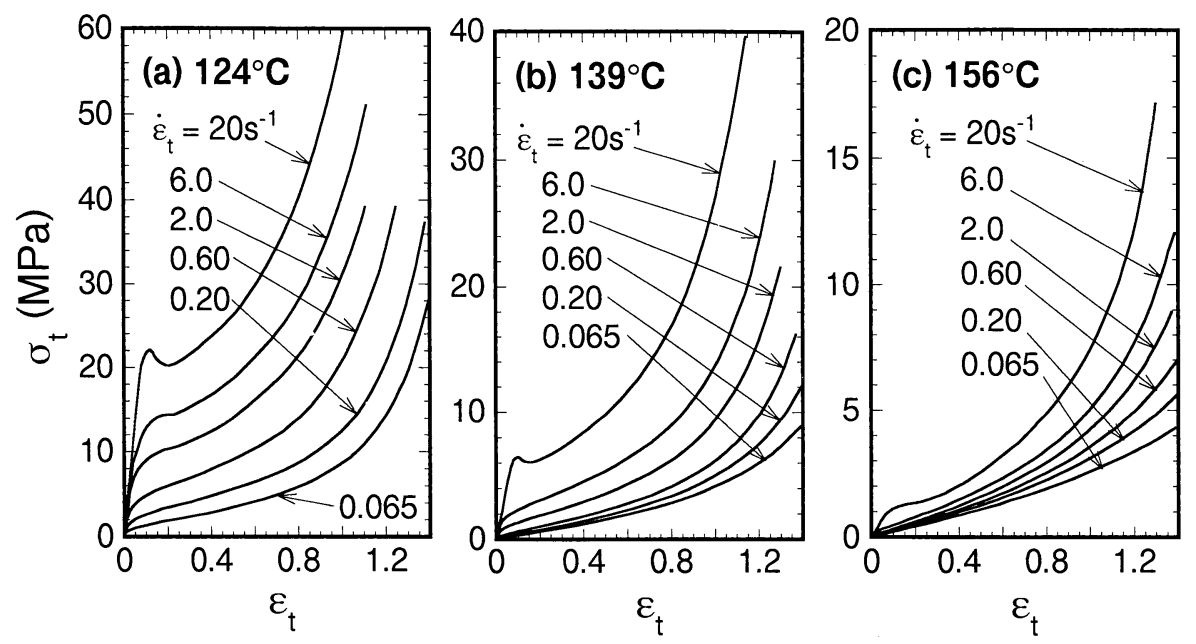

Fig. 1 Relationship between true tensile stress, $\sigma_{\mathrm{t}}$, and true strain, $\varepsilon_{\mathrm{t}}$, for polymethyl methacrylate (PMMA) in its rubbery temperature range. Stretching was performed at various true strain rates. 
0.1 付近において極大值をとり, $\varepsilon_{\mathrm{t}}=0.2$ 付近まで若干低下した後 (2)の曲線をさらに比例的に大きくしたような応答を示したもの, である． $\sigma_{\mathrm{t}}-\varepsilon_{\mathrm{t}}$ 曲線の形状は，より高ひずみ速度あるいはより低 温になるほど, $(1) \rightarrow(2) \rightarrow(3)$ の順に連続的に変化した.

\section{$3 \cdot 2$ 等真ひずみ速度延伸後の応力緩和}

等真ひずみ速度延伸後の応力緩和は, 上述のように, $\varepsilon_{\mathrm{t}}=0.077$ を任意に選んだ単位ひずみ量として，その $1 \sim 16$ 倍の 5 段階のひ ずみ $(\times 1 \sim \times 16$ と表示する)において測定した． 延伸過程におけ る $\sigma_{\mathrm{t}}-\varepsilon_{\mathrm{t}}$ 曲線とこれらの延伸停止ひずみとの関係を明確にするた めに，延伸開始から応力緩和初期にかけての時間領域における $\sigma_{\mathrm{t}}$

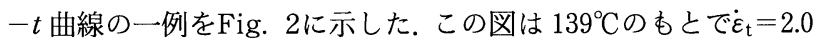
$\mathrm{s}^{-1}$ で延伸後応力緩和させた際の結果である. 横軸の $t$ は延伸開 始時を 0 とする経過時間を表し, 図の上側に示した横軸は延伸過

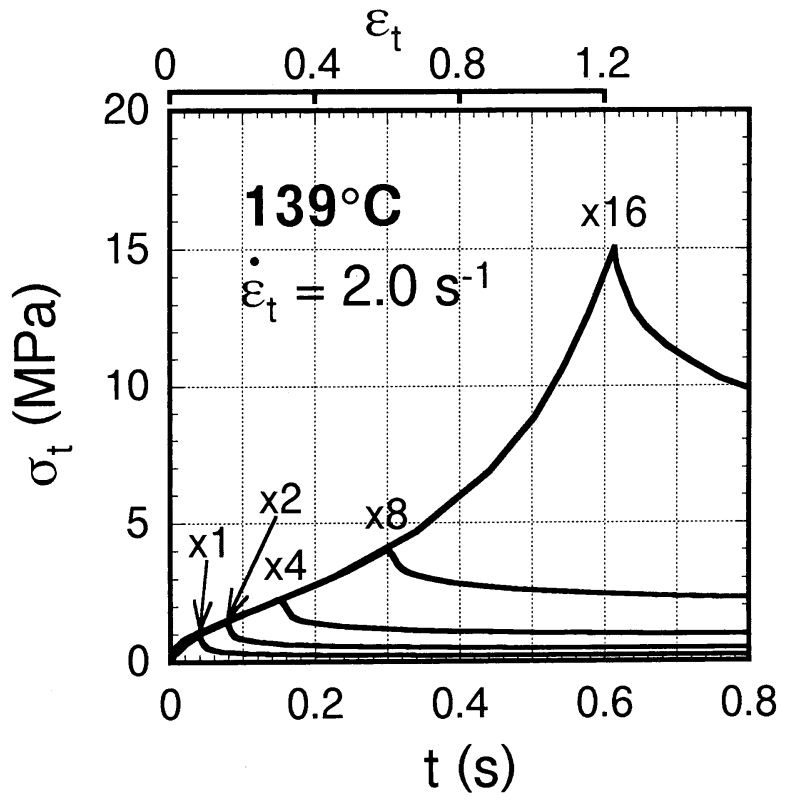

Fig. 2 True tensile stress, $\sigma_{\text {t, }}$ during stretching and subsequent stress relaxation processes as a function of time, $t$. Stretching was performed at a strain rate of $2.0 \mathrm{~s}^{-1}$ and a temperature of $139^{\circ} \mathrm{C}$.
程におけるひずみ $\varepsilon_{\mathrm{t}}$ を表している. 応力緩和を測定したひずみの 内, $\times 8$ および $\times 16$ のひずみは $\sigma_{\mathrm{t}}-\varepsilon_{\mathrm{t}}$ 曲線における傾きの再増加 領域に含まれることがわかる. Fig. 1に示したように, 今回得ら れたすべての $\sigma_{\mathrm{t}}-\varepsilon_{\mathrm{t}}$ 曲線は $\varepsilon_{\mathrm{t}} \geqq 0.5$ のひずみ域でその傾きがひず みの増大とともに増加していたので， $\times 8$ および $\times 16$ のひずみは 延伸条件之無関係に常にこの傾きの増加域に含まれることがわか る.

応力緩和過程における $\sigma_{\mathrm{t}}$ の変化を, 緩和開始後の経過時間 $t_{\mathrm{r}}$ の関数としてFig. 3に両対数表示した. パラメ夕は延伸停止ひず

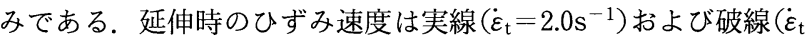
$\left.=0.20 \mathrm{~s}^{-1}\right)$ で区別した。 なお, $124^{\circ} \mathrm{C}((\mathrm{a})$ 図 $)$ において $\dot{\varepsilon}_{\mathrm{t}}=2.0 \mathrm{~s}^{-1}$, $\times 16$ のデータがないのは，この条件では $\times 16$ のひずみに達する 前に試験片が破断したことによる. 各温度において延伸停止ひず みが等しい場合の結果同士を比較すると, 延伸時のひずみ速度が 応力緩和挙動へおよぼす効果は緩和の長時間側ではなくなること がわかる.ひずみ速度の効果が消滅するために要する時間は延伸 停止ひずみが小さいほど短く, 粗く見れば, $\dot{\varepsilon}_{\mathrm{t}}=0.20 \mathrm{~s}^{-1}$ の速度で 延伸を加えるために要した時間と同程度であった．今回実験を 行った中で最も低温の $124^{\circ} \mathrm{C}((\mathrm{a})$ 図)では, 緩和応力は短時間側 で急激に低下した後 $t_{\mathrm{r}}=10^{1} \mathrm{~s}$ 付近以降では傾き, $\operatorname{d} \log \sigma_{\mathrm{t}} / \mathrm{d} \log t_{\mathrm{r}}$, -0.1 程度で緩やかに低下した(目安として, -0.1 の傾きを図中 に示した). 延伸停止ひずみが増加すると, 緩和応力曲線の短時間 側の勾配が緩やかになるとともに，傾きが約 -0.1 となる $t_{\mathrm{r}}=10^{1} \mathrm{~s}$ 付近以降の応力はひずみの増加とほぼ同じ割合で増加した．ただ し， 延伸停止ひずみが $\times 8$ 以上の緩和応力曲線では， $\times 4$ までの 曲線之比べて, $t_{\mathrm{r}}=10^{1} \mathrm{~s}$ 付近以降の傾きが若干大きくなる形状変 化が認められた. 温度が $139,156^{\circ} \mathrm{C}((\mathrm{b})$ 図, (c)図) と上昇するに したがって, 緩和応力はより短時間側から -0.1 程度の傾きで緩 やかに低下した後長時間側において急激に低下する挙動へと連続 的に変化した.すなわち, $139^{\circ} \mathrm{C}\left((\mathrm{b})\right.$ 図) および $156^{\circ} \mathrm{C}((\mathrm{c})$ 図)の緩 和応力は, それぞれ, $t_{\mathrm{r}}=10^{0} \sim 10^{3} \mathrm{~s}$ 付近および $t_{\mathrm{r}}=10^{-1} \sim 10^{2} \mathrm{~s}$ 付 近において傾き約一 0.1 で低下した後徐々に傾きを増しながら低 下した。 延伸停止ひずみの増大は, $124^{\circ} \mathrm{C}$ 場合と同じく, 緩和応 力曲線の短時間側の勾配を緩やかにし, 傾きが約一 0.1 となる領 域以降の応力をひずみの増加とほぼ同じ割合で増加させた。な お, $156^{\circ} \mathrm{C}((\mathrm{c})$ 図 $)$ の $\times 16$ の場合に $t_{\mathrm{r}}=10^{3} \mathrm{~s}$ 付近以降の緩和挙動が
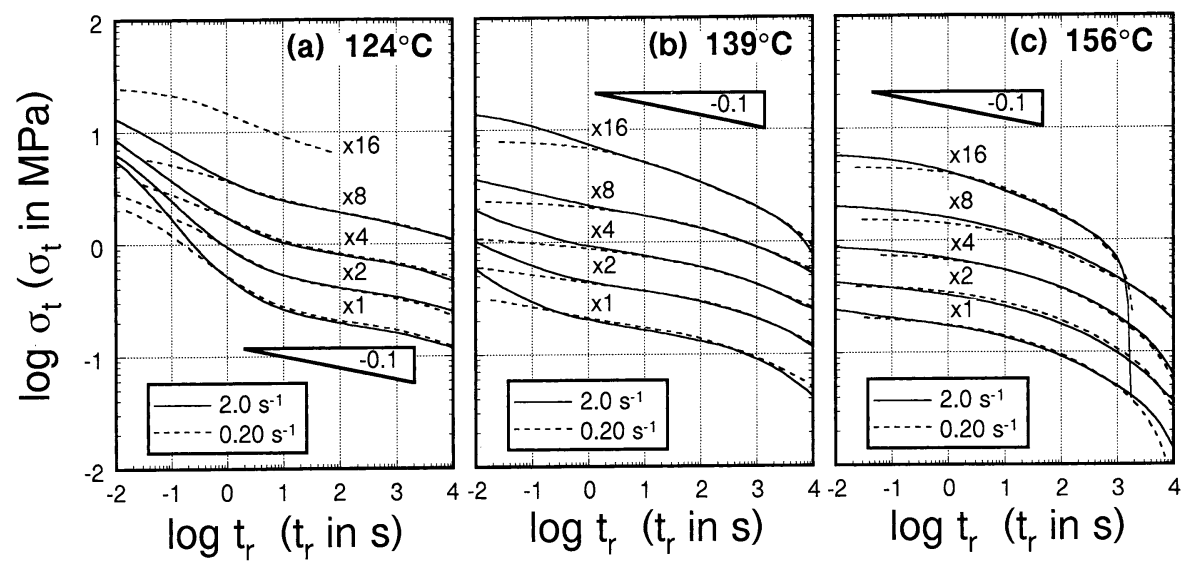

Fig. 3 Double-logarithmic plot of relaxation stress, $\sigma_{\mathrm{t}}$, against time elapsed in the relaxation process, $t_{\mathrm{r}}$, for largely stretched PMMA. 
他と極端に異なっているのは，この付近の $t$ において試験片が糸 を引くように破断したためである. 同一の延伸停止ひずみでは， 傾きが約一 0.1 となる領域以降の応力強度および緩和曲線の形状 は温度に依存せずほぼ等しかった。

\section{考 察}

Fig. 1に示したように, $\sigma_{\mathrm{t}}-\varepsilon_{\mathrm{t}}$ 曲線は延伸条件に依存して $3 つ$ のパターンで現れた。最も高温かつ低ひずみ速度側で現れたパ ターン $(1) の \sigma_{\mathrm{t}}-\varepsilon_{\mathrm{t}}$ 曲線は分子鎖の絡み合いが疑似架橋点として作 用した無定形高分子のゴム状応答と単純に理解できる。なぜな ら, この場合の $\sigma_{\mathrm{t}}-\varepsilon_{\mathrm{t}}$ 曲線は延伸初期に比較的長い弾性域を有 し, かつ, その弾性率 2 3MPa が供試 PMMA の線形緩和弾性 率のゴム状平坦域の值と一致する (Fig. 4参照)からである. $\varepsilon_{\mathrm{t}} \geqq$ 0.5 のひずみ域における傾きの漸増は，この付近から絡み合い間 分子鎖の伸びきりが生じ始めたことを示すすのと捉えることがで きる.このように，パターン(1)の $\sigma_{\mathrm{t}}-\varepsilon_{\mathrm{t}}$ 曲線が通常のゴム状物質 の大変形応答と理解されるので, これよりも高ひずみ速度あるい は低温側で観察され，10MPa を超える初期弾性率を示したパ ターン $(2)$ および(3)の $\sigma_{\mathrm{t}}-\varepsilon_{\mathrm{t}}$ 曲線は供試材のゴム状応答よりあ短時 間側の緩和機構，すなわち，転移領域の影響を受けたものである ことがわかる。

今回の実験条件の中で最あ高ひずみ速度あるいは低温側におい て観察されたパターン(3)の曲線は, 今回観察された最も特徴的な $\sigma_{\mathrm{t}}-\varepsilon_{\mathrm{t}}$ 曲線であり, $\varepsilon_{\mathrm{t}}=0.1$ 付近に明確な応力の極大点を有すると いう非線形を示した。，パターン(1)〜(3)の連続的なひずみ速度およ び温度依存性より，この応力極大は応力ーひずみ関係がより強く 転移領域の影響を受ける場合に現れることがわかる、転移領域よ りも短時間側においては, $T_{\mathrm{g}}$ 以上の温度においても, 骨格鎖の緩 和が局所的にしか生じないためにポリマーはガラス的な緩和挙動 を示すことが知られていること，および，応力極大が観察された ひずみがガラス状態にある供試材の降伏ひずみとほぼ等しいこと を考え合わせれば，このパターン(3)の曲線において認められた応 力極大の発現はガラス状高分子の降伏と同一の現象であることが 応力ーひずみ関係だけからも容易に予測される．応力極大が現れ ないという意味ではパ夕ーン(2)に分類できる $156^{\circ} \mathrm{C} の \dot{\varepsilon}_{\mathrm{t}}=20 \mathrm{~s}^{-1}$ および $124^{\circ} \mathrm{C}$ 的 $=2.0 \mathrm{~s}^{-1}$ の $\sigma_{\mathrm{t}}-\varepsilon_{\mathrm{t}}$ 曲線も $\varepsilon_{\mathrm{t}}=0.2$ 付近の傾きが供 試材のゴムの弾性率 $(2 \sim 3 \mathrm{MPa})$ よりも明らかに低くなっており, パターン(3)之同一の非線形挙動を示していることがわかる.この ように, ガラス状高分子の降伏ときわめてよく似た非線形は $156^{\circ} \mathrm{C}\left(=T_{\mathrm{g}}+40^{\circ} \mathrm{C}\right)$ という高温においても観察されたので, これ は高速変形を受ける無定形高分子メルトにおいて温度とは無関係 に観察される現象と考えられる.

このような非線形が生じるメカニズムについて, 応力緩和挙動 に基づいて考えてみる．なお，上述のように $\times 8$ 以上のひずみを 与えた場合には応力ーひずみ曲線の傾きの再増加 (Fig. 1)および 緩和応力曲線の形状の变化(Fig. 3)が現れ, 絡み合い間分子鎖の 伸びきりに関係する現象が生じていると考えられることに加え て,ここで取り扱いたい降伏と類似の非線形が $\varepsilon_{\mathrm{t}}=0.2 \sim 0.3$ 付近 までに生じていることから，以下では， $\times 4\left(\varepsilon_{\mathrm{t}}=0.31\right)$ までのひず みを加えた場合の結果についてのみ考えることにする.

Fig. 3に示した大変形後の緩和応力曲線は, 定性的には, 低温 側あるいは短時間側から順に転移領域, ゴム状平坦域そして終端
流動域の緩和挙動を示している. ゴム状平坦域以降では, 同一ひ ずみであれば, 温度が異なっても応力の強度および曲線の形状は ほぼ等しく, また, ひずみの増大は曲線の形状は変えずに単に上 方へシフトさせる効果を有した。 これらはすべて線形の応力緩和 挙動の特徴である. したがって, ゴム状平坦域以降の緩和挙動に ついては, 応力ーひずみ曲線に認められた非線形挙動とは無関係 に, 線形応答であることがただちに予想される.これを確かめる ために, Fig. 3のデー夕を緩和弾性率表現してその合成曲線を作 成することを試みた，その結果をFig. 4に示す. Fig. 3に示した ようにひずみ速度の効果は緩和の長時間側で消滅するので, ここ では $\dot{\varepsilon}_{\mathrm{t}}=2.0 \mathrm{~s}^{-1}$ のデー夕のみを用いた. 基準温度は $124^{\circ} \mathrm{C}$ と, ゴ ム状平坦域から終端域にかけての曲線が最もうまく重なり合うよ うに時間軸方向にシフトさせた．縦シフトにおいて密度変化の効 果は無視した。. シフトファクタ $\log a_{\mathrm{T}}$ は 139 および $156^{\circ} \mathrm{C}$ に対し て，それぞれ，-1.5 および-2.8 となった．また，図中の破線は， $124^{\circ} \mathrm{C}$ において公称ひずみ $\varepsilon_{\mathrm{n}}=0.01$ を公称ひずみ速度 $\dot{\varepsilon}_{\mathrm{n}}=0.07 \mathrm{~s}^{-1}$ で与えて測定した供試 PMMA の線形緩和弾性率曲線を示してい る. 延伸に要した時間の効果をできるだけ排除して図示するため に, 各ひずみ量を与えるために要した延伸時間よりあ長時間側の $t_{\mathrm{r}}$ 領域においてのみ緩和弾性率曲線をプロットした，得られた緩 和弾性率曲線は転移領域ではひずみが大きいほど值が小さくなる という延伸条件依存性を有したが，ゴム状平坦域以降においては ほぼ 1 本の曲線となり, 線形の緩和弾性率曲線(破線)とも一致し た.このようにゴム状平坦域以降の緩和挙動が線形緩和と同一で あることが確認されたので, 延伸開始直後に現れる非線形は供試 材の絡み合い構造には影響を与えない機構によるものであること がわかる. 言い換えればFig. 4の結果は, 高分子ガラスの降伏に 類似した非線形が転移領域の緩和特性の变化により発現するもの であることを示している.

そこで, 変形により生じた転移領域の緩和挙動の変化について 考えてみる. Fig. 4に示したように, 転移領域の緩和弾性率は与 えたひずみが大きいほどその值は低く, かつ, すべての曲線が線 形の緩和曲線(破線)よりも常に低い值を示した．上述のように，

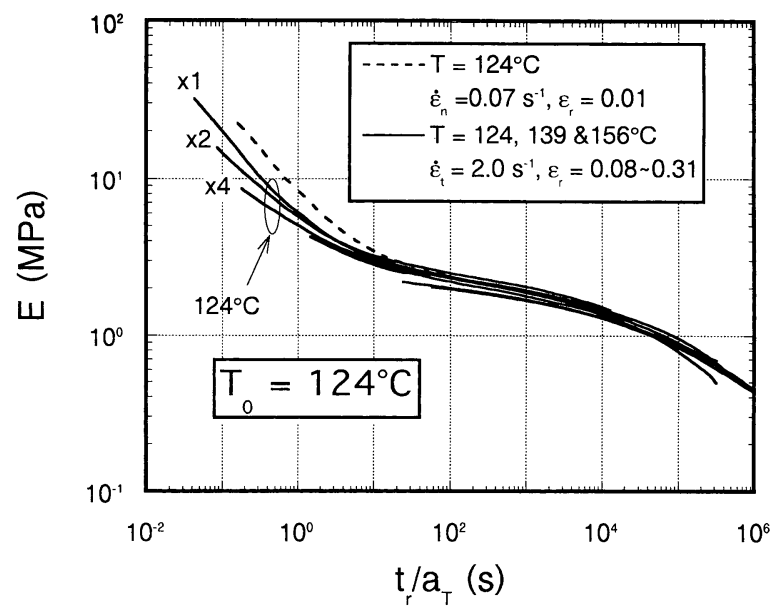

Fig. 4 Superimposed relaxation moduli for largely deformed PMMA (solid lines). Dashed line designates relaxation modulus measured at $124^{\circ} \mathrm{C}$ with a small imposed strain of 0.01 . 
Fig. 4には延伸に要した時間よりも長時間側の緩和曲線を示した ので, 曲線の短時間側の端の位置が延伸に要した時間を表してい る. $124^{\circ} \mathrm{C}$ で測定されたデータを見ればわかるように, $\dot{\varepsilon}_{\mathrm{t}}=2.0 \mathrm{~s}^{-1}$ で延伸した後の緩和弾性率は, いずれあ, 線形のそれと同じかよ り短時間でひずみを加えたあとに測定されたあのである.つま り, 転移領域における緩和弾性率の低下は, 線形の重ね合わせに よる見かけ上のあのではなく, 高速で加えられた変形により生じ たものであることがわかる，そして，この弾性率の低下はひずみ が大きくなるほど顕著になる.これらの結果は, 高速変形下で観 察された降伏に類似した非線形が変形の増大に伴う転移領域の弾 性率低下に起因していることを示している.

既報のように, ガラス状高分子の降伏は変形の増大に伴ってガ ラスの構造が未変形時の準平衡構造から変形条件に対応した非平 衡構造へと連続的に変化することにより系が緩和しやすくなる際 の過渡現象として説明できることがわかってきてい る9),12),15), 16). ガラス状態における分子鎖は, その低い熱エネル ギのために, 元々局所的なモードによる緩和しか許されていな い. したがって, 高分子ガラスの降伏は局所的なモードでの分子 鎖の緩和が変形とともに生じやすくなることに起因すると言い換 えることができる. 今回メルト状態において観察された, 降伏に 類似した非線形の発現と転移領域の緩和弾性率低下との対応関係 は, 変形によって局所的なモードでの分子鎤の緩和が生じやすく なることがその非線形挙動の原因であることを示している.つま り,メルト状態において変形初期に観察された非線形挙動はガラ ス状態における降伏と同一の機構により発現したといえる.すな わち, ガラス転移温度より高温においても, 転移領域の緩和機構 が巨視的な応答に影響するほど高速で変形が加えられた場合に は, 無定形高分子はガラス状態と全く同じ機構の非線形粘弾性挙 動を示すことが明らかとなった．この結果は，分子鎖が局所的に しか緩和できないような条件において大変形が加えられた場合に は，系の熱エネルギ状態とは無関係に，分子鎖の局所的な緩和に 関係する構造の等温変化が生じることを示している.

\section{5. 結言}

ゴム状温度領域において無定形ポリメタクリル酸メチルを高ひ
ずみ速度で伸長大变形させた際の応力ーひずみ応答および大変形 後の応力緩和挙動を測定した。その結果, ガラス転移温度より高 温のメルト状態においてもガラス状態と同一の機構により降伏が 生じることが明らかとなった。このことから，ガラス状態におけ る非線形粘弾性の原因として報告されている変形による系の等温 構造変化が，系の熱エネルギ状態とは無関係に，分子鎖が局所的 なモードでしか緩和できない条件において有限変形が加えられた 場合に一般的に生じるものであることが示された.

\section{参考文献}

1) Ferry JD, "Viscoelastic Properties of Polymers", 3rd Ed (1980), Wiley, NY, Chap 10, p257.

2) Isono $\mathrm{Y}$, Itoh $\mathrm{K}$, Komiyatani $\mathrm{T}$, Fujimoto $\mathrm{T}$, Macromolecules, 24, 4429 (1991).

3) McKenna GB, J Non-Cryst Solids, 172-174, 756 (1994).

4) Robertson RE, J Chem Phys, 44, 3950 (1966).

5) Rendell RW, Ngai KL, Fong GR, Yee AF, Bankert RJ, Polym Eng Sci, 27, 2 (1987).

6) Shay Jr RM, Caruthers JM, J Rheol, 30, 781 (1986).

7) Lefebvre JM, Escaig B, J Mater Sci, 20, 438 (1985).

8) Oleynik E, Progr Colloid Polym Sci, 80, 140 (1989).

9) Nanzai Y, Polym Eng Sci, 30, 96 (1990).

10) Nanzai Y, konishi T, Ueda S, J Mater Sci, 26, 4477 (1991).

11) Nanzai Y, J Non-Cryst Solids, 131-133, 516 (1991).

12) Nanzai Y, Progr Polym Sci, 18, 437 (1993).

13) Nanzai Y, JSME Int J, 37, 149 (1994).

14) Nanzai Y, Nakayama N, J Non-Cryst Solids, 172-174, 771 (1994)

15）吉岡, 杉本, 南斎, 上田, 日本レオロジ一学会誌, 19, 57 (1991).

16) Yoshioka S, Usada H, Nanzai Y, J Non-Cryst Solids, 172-174, 765 (1994). 